\title{
UJI EFEKTIFITAS ANTIBAKTERI MINYAK ATSIRI SEREH DAPUR SEBAGAI BAHAN MEDIKAMEN SALURAN AKAR TERHADAP BAKTERI ENTEROCOCCUS FAECALIS
}

\author{
${ }^{1}$ Mario S. Howarto \\ ${ }^{2}$ Pemsi M. Wowor \\ ${ }^{3}$ Christy N. Mintjelungan \\ ${ }^{1}$ Kandidat Skripsi Program Studi Pendidikan Dokter Gigi Fakultas Kedokteran \\ ${ }^{2}$ Bagian Farmakologi Fakultas Kedokteran \\ ${ }^{3}$ Program Studi Kedokteran Gigi Fakultas Kedokteran \\ Universitas Sam Ratulangi Manado \\ Email: Mariohowarto@yahoo.com
}

\begin{abstract}
Endodontics is the a type of treatment that aims to keep the teeth in function. Disinfection of the root canal is very important in endodontic treatment. Root canal disinfection can be done by giving the material a root canal medication. One of the bacteria that causes the failure of root canal treatment is the bacterium Enterococcus faecalis. The lemongrass essential oil contains geranial, neral, and mirsen which have antimicrobial activity against Gram-positive and Gram-negative. This study aimed to determine whether the lemongrass essential oil was effective against bacteria Enterococcus faecalis. This was an experimental study using post test only control group design with agar plate diffusion method. Samples consisted of a group of lemongrass essential oil with several concentrations: $25 \%, 50 \%, 75 \%, 100 \%$, each consisted of 4 samples. The 16 control groups consisted of positive and negative groups. Diameter of inhibition was determined by the ability to inhibit Enterococcus faecalis cultured on MHA agar. The results showed that the average inhibitory diameter of $25 \%$ lemongrass essential oil was $2.60 \mathrm{~mm}$; of $50 \%$ was $4.73 \mathrm{~mm}$; of $75 \%$ was $4.50 \mathrm{~mm}$; and of $100 \%$ was $5.34 \mathrm{~mm}$. Conclusion: Lemongrass essential oil showed an antibacterial effect to inhibit the growth of bacteria Enterococcus faecalis.

Keywords: enterococcus faecalis, lemongrass oil, antibacerial
\end{abstract}

\begin{abstract}
Abstrak: Endodontik merupakan salah satu jenis perawatan yang bertujuan mempertahankan gigi agar tetap dapat berfungsi. Disinfeksi saluran akar sangat penting dalam perawatan endodontik. Disinfeksi saluran akar dapat dilakukan dengan memberi bahan medikamen saluran akar. Salah satu bakteri yang menyebabkan kegagalan perawatan saluran akar ialah bakteri Enterococcus faecalis. Minyak atsiri sereh dapur mengandung geranial, neral dan mirsen yang memiliki aktifitas antimikrobapada gram positif dan gram negatif. Penelitian ini bertujuan untuk mengetahui apakah minyak atsiri sereh dapur memiliki efek terhadap bakteri Enterococcus faecalis. Penelitian ini menggunakan metode eksperimental dengan desain post test only control group design dan metode difusi lempeng agar. Sampel penelitian terdiri dari kelompok minyak atsiri sereh dapur dengan konsentrasi $25 \%$, 50\%, 75\%, dan 100\% yang masing-masing terdiri dari 4 sampel; 16 kelompok kontrol terdiri atas kelompok positif dan negatif. Diameter hambat ditentukan berdasarkan kemampuan menghambat Enterococcus faecalis yang dibiakkan pada media agar MHA. Hasil penelitian memperlihatkan rata-rata diameter hambat minyak atsiri sereh dapur dengan konsentrasi $25 \%$ sebesar 2,60 mm, $50 \%$ sebesar $4,73 \mathrm{~mm}$, 75\% sebesar 4,50 mm, dan $100 \%$ sebesar 5,34 mm. Simpulan: Minyak atsiri sereh dapur memiliki efek antibakteri untuk menghambat pertumbuhan bakteri Enterococcus faecalis.
\end{abstract}

Kata kunci: enterococcus faecalis, sereh dapur, antibakteri 
Endodontik merupakan salah satu jenis perawatan yang bertujuan mempertahankan gigi agar tetap dapat berfungsi. Tahap perawatan endodontik ialah preparasi, disinfeksi, dan pengisian saluran akar. Disinfeksi saluran akar sangat penting dalam perawatan endodontik. Disinfeksi saluran akar dapat dilakukan dengan memberi bahan medikamen saluran akar sehingga dapat mengeliminasi mikroorganisme patogen dalam saluran akar. ${ }^{1}$

Bakteri Enterococcus faecalis merupakan bakteri komensal dalam mulut dengan jumlah kecil. Bakteri ini dapat menjadi patogen bila diluar tempatnya. Bakteri Enterococcus faecalis dapat masuk ke dalam saluran akar melalui kerusakan gigi yang mencapai pulpa. ${ }^{2}$ Enterococcus faecalis bertanggung jawab terhadap 8090\% infeksi saluran akar oleh Enterococci dan biasanya merupakan satu-satunya spessies enterokokus yang diisolasi dari saluran akar yang telah diisi. Enterococcus faecalis dapat bertahan dalam saluran akar tanpa dukungan dari bakteri lain. organisme ini dapat menghasilkan perubahan patologis melalui produksi racun atau secara tidak langsung melalui proses inflamasi. ${ }^{3}$

Medikamen saluran akar sangat membantu untuk mengeliminasi bakteri yang masih tertinggal setelah dilakukan preparasi atau setidaknya menghambat infeksi berulang pada saluran akar. ${ }^{4}$ Obat saluran akar yang sering digunakan sejak dulu ialah golongan fenol, dan meliputi formokresol, camphorated paracholorophenol, eugenol, metakresilasetat, dan halida (iodin-potasium iodida). Namun obat ini bersifat antigenik dan sitotoksik yang hanya efektif dalam waktu singkat. Obat yang dianggap baik sekarang ialah kalsium hidroksida $\left(\mathrm{Ca}(\mathrm{OH})_{2}{ }^{5}\right.$

Kalsium hidroksida atau $\mathrm{Ca}(\mathrm{OH})_{2}$ merupakan bahan medikamen saluran akar yang saat ini paling sering digunakan. Kalchinov dkk melaporkan kalsium hidroksida merupakan obat yang banyak digunakan sebagai dressing intrakanal pada terapi endodontik dan memiliki antibakteri yang signifikan. Akan tetapi kalsium hidroksida juga memiliki beberapa kelemahan yakni peradangan selama beberapa hari pertama, tidak padat, mudah larut dan positif mengandung bakteri setelah perawatan, ${ }^{2,5}$ sehingga sangat diharapkan perkembangan bahan medikasi saluran akar yang berasal dari alam yang lebih kompatibel terhadap jaringan namun tetap memiliki kemampuan antibakteri yang sama dengan bahan yang non-biologi.

Indonesia kaya akan berbagai jenis tumbuhan obat yang banyak digunakan untuk pengobatan oleh masyarakat zaman dahulu sampai sekarang. Salah satu bahan alam yang sering digunakan ialah minyak atsiri. Minyak atsiri merupakan salah satu produk bahan rempah. Minyak ini sangat mudah menguap dan berbau wangi sesuai warna tanaman penghasil. Salah satu tanaman penghasil minyak atsiri adalah sereh dapur. Sereh dapur merupakan salah satu bumbu dapur seperti lengkuas, daun salam, kunyit, dan lain-lain. ${ }^{6}$ Beberapa bahan contoh kimia yang terdapat pada minyak atsiri sereh dapur ialah geranial, neral dan mirsen. Senyawa tersebut menunjukkan bahwa minyak atsiri sereh dapur memiliki aktifitas antimikroba pada gram positif dan gram negatif. ${ }^{7}$

Menurut Nisaa senyawa yang terkandung dalam minyak atsiri sereh dapur efektif dalam menghambat pertumbuhan koloni bakteri Enterococcus faecalis. ${ }^{8}$ Kandungan geranial, neral dan mirsen dalam sereh dapur juga menunjukkan potensi sebagai antitoksik dan penangkal radikal bebas.

Berdasarkan uraian diatas, peneliti tertarik untuk melakukan penelitian tentang uji efek antibakteri minyak atsiri sereh dapur sebagai bahan medikamen saluran akar terhadap bakteri Enterococcus faecalis.

\section{METODE PENELITIAN}

Penelitian ini merupakan penelitian eksperimental dengan menggunakan desain post test only control group design. Tempat penelitian dilaksanakan di Laboratorium Farmasi Fakultas MIPA Universitas Sam Ratulangi, Manado. Waktu Penelitian ini 
dilaksanakan pada bulan FebruariSeptember 2015. Subjek penelitian ini ialah bakteri Enterococcus faecalis. Penelitian ini menggunakan 2 variabel, yaitu variabel intervensi: Minyak atsiri sereh dapur pada konsentrasi 25\%, 50\%, 75\%, dan 100\%. Variabel kontrol menggunakan klindamisin sebagai kontrol positif dan carboxy methyl cellulose (CMC) sebagai kontrol negatif.

Minyak atsiri sereh dapur adalah minyak yang dihasilkan dari sereh dapur melalui proses destilasi uap yang dilakukan di Laboratorium Farmasi Fakultas MIPA Universitas Sam Ratulangi. Minyak atsiri sereh dapur dibuat dengan konsentrasi tertentu dengan mencampurkan 100\% minyak atsiri sereh dapur dengan carboxy methyl cellulose (CMC). Konsentrasi yang digunakan diperoleh dengan menggunakan rumus: $\mathrm{m} 1 . \mathrm{v} 1=\mathrm{m} 2 . \mathrm{v} 2$

Ket:

$$
\begin{aligned}
& \mathrm{m} 1=\text { molaritas sebelum pengenceran } \\
& \mathrm{m} 2=\text { molaritas setelah pengenceran } \\
& \mathrm{v} 1=\text { volume sebelum pengenceran } \\
& \mathrm{v} 2=\text { volume setelah pengenceran }
\end{aligned}
$$

Bakteri Enterococcus faecalis yang merupakan biakan murni dari bakteri Enterococcus faecalis pada media BHI-B yang diperoleh dari Laboratorium Farmasi Fakultas MIPA Universitas Sam Ratulangi Manado yang kemudian dibiakkan pada media MHA.

Pembuatan minyak atsiri dilakukan di Laboratorium Farmasi Fakultas MIPA Universitas Sam Ratulangi dengan cara sereh dapur utuh dibersihkan lalu dipotong dengan ukuran $\pm 1 \mathrm{~cm}$, kemudian dimasukkan ke dalam labu destilasi. Pada labu destilasi yang lain diisi dengan akuades dan dipanaskan pada suhu $90^{\circ} \mathrm{C}$. Uap air akan mengalir ke labu destilasi sereh dapur sehingga menghasilkan campuran sereh dapur dan akuades. Hasil dari destilasi ditampung di botol kaca steril dan didiamkan pada suhu kamar. Cairan pembawa akan terpisah dari komponen target karena berbeda massa jenis dan akan terpisah dengan mudah karena gaya gravitasi.

Alat-alat yang digunakan dalam penelitian ini disterilkan terlebih dahulu. Alat-alat gelas disterilkan dalam oven pada suhu $170^{\circ} \mathrm{C}$ selama \pm 2 jam. Media disterilkan dalam autoclave pada suhu $121^{\circ} \mathrm{C}$ selama 15 menit.

BHI ditimbang sebanyak 9,3 gram lalu dicampur dengan aquades sebanyak $250 \mathrm{ml}$ dalam tabung erlenmeyer dan dipanaskan di kompor listrik selama \pm 15 menit. Setelah itu, pindahkan ke dalam autoclave selama 15 menit, kemudian dituang ke tabung reaksi untuk didinginkan pada suhu ruangan.

Pembuatan media MHA dilakukan dengan menimbang 5 gram agar, dimasukkan ke dalam erlenmeyer yang sudah berisi $250 \mathrm{ml}$ akuades lalu diaduk, kemudian di autoclave pada suhu $121^{\circ} \mathrm{C}$ tekanan 1 atm selama 15 menit. kemudian dituang ke petridish steril untuk didinginkan pada suhu ruangan.

Larutan baku McFarland terdiri atas dua komponen yaitu larutan $\mathrm{BaCl}_{2} 1 \%$ dan $\mathrm{H}_{2} \mathrm{SO}_{4} 1 \%$. Larutan $\mathrm{BaCl}_{2} 1 \%$ sebanyak 0,05 ml dicampurkan dengan larutan $\mathrm{H}_{2} \mathrm{SO}_{4} 1 \%$ sebanyak 9,95 $\mathrm{ml}$ dan dikocok homogen. Nilai absorban larutan baku McFarland 0,5 ekuivalen dengan suspensi sel bakteri dengan konsentrasi 1,5 x $10^{8}$ $\mathrm{CFU} / \mathrm{ml}$.

Sampel bakteri Enterococcus faecalis diambil dari stok bakteri murni Laboratorium Farmasi Fakultas MIPA Universitas Sam Ratulangi Manado, dan diperbanyak dengan media BHI-B di Laboratorium Farmasi Fakultas MIPA Universitas Sam Ratulangi Manado.

Bakteri yang didapat diperoleh dari stok bakteri murni Laboratorium Kimia Fakultas MIPA Universitas Sam Ratulangi Manado dan diperbanyak dengan menggunakan media BHI-B dengan perbandingan $1: 3$. Setelah itu dimasukkan ke dalam anaerobic jar dan diinkubasi pada suhu $37^{\circ} \mathrm{C}$ selama 24 jam.

Sebelum bakteri ditanam pada media MHA, bagian belakang cawan petri dibagi menjadi tiga bagian dengan menggunakan spidol. Bakteri yang sudah diinkubasi diambil dengan kapas lidi steril dimasukan ke dalam tabung reaksi dan dicampurkan 
dengan $\mathrm{NaCl} \quad 0,9 \%$ hingga mencapai standar kekeruhan larutan McFarland. Bakteri yang sudah dilarutkan diambil dengan menggunakan kapas lidi steril lalu dioleskan secara merata pada media MHA. Cakram kertas saring yang ditetesi minyak atsiri sereh dapur diletakkan dengan pinset pada satu bagian cawan petri. Cakram kertas saring yang menggunakan antibiotik klindamisin diletakkan pada bagian satu bagian yang lain sebagai kontrol positif. Cakram kertas saring yang menggunakan CMC diletakkan pada satu bagian sebagai kontrol negatif.

Setiap pekerjaan laboratorium dilakukan di dekat api bunsen agar sterilitas terjaga. Dimasukkan ke dalam anaerobic jar dan diinkubasi pada suhu $37^{\circ} \mathrm{C}$ selama 24 jam.

Metode yang digunakan ialah metode Difusi Lempeng Agar, MHA disediakan sebanyak 16 cawan petri. Enterococcus faecalis diambil dari stok bakteri murni Laboratorium Farmasi Fakultas MIPA Universitas Sam Ratulangi Manado. Bakteri tersebut diperbanyak dengan memasukkannya dalam tabung reaksi yang berisi media BHI-B lalu dimasukkan ke dalam anaerobic jar dan diinkubasi pada suhu $37{ }^{\circ} \mathrm{C}$ selama 24 jam. Kemudian bakteri dioles dengan menggunakan lidi kapas steril pada permukaan media MHA.

Kertas saring dibentuk seperti cakram dengan menggunakan perforator sebanyak 24 buah, Masing-masing cawan petri diletakkan satu cakram yang diberi minyak atsiri sereh dapur, satu sediaan cakram antibiotik klindamisin digunakan sebagai kelompok kontrol positif, sedangkan satu cakram akuades sebagai kelompok kontrol negatif. Perlakuan dibuat masing-masing konsentrasi. Masing-masing konsentrasi dibuat dengan volume $10 \mathrm{ml}$. Penelitian ini dibagi menjadi 6

kelompok:

Kelompok perlakuan 1: 2,5ml minyak atsiri sereh dapur dengan konsentrasi sampel $100 \%$ ditambah dengan $7,5 \mathrm{ml}$ CMC menghasilkan minyak atsiri sereh dengan konsentrasi 25\%. Kelompok perlakuan 2: $5 \mathrm{ml}$ minyak atsiri sereh dapur dengan konsentrasi sampel 100\% ditambah dengan $5 \mathrm{ml} \mathrm{CMC} \mathrm{menghasilkan}$ minyak atsiri sereh dengan konsentrasi 50\%. Kelompok perlakuan 3: 7,5ml minyak atsiri sereh dapur dengan konsentrasi sampel $100 \%$ ditambah dengan $2,5 \mathrm{ml}$ CMC menghasilkan minyak atsiri sereh dapur dengan konsentrasi 75\%. Kelompok perlakuan 4: $10 \mathrm{ml}$ minyak atsiri sereh dapur dengan konsentrasi 100\%. Kelompok kontrol positif $(\mathrm{K}+)$ : antibiotik klindamisin dan kelompok kontrol negatif (K-): cakram carboxy methyl cellulose (CMC)

Cakram yang telah diberi minyak atsiri sereh dapur dengan berbagai konsentrasi diletakkan di media MHA lalu dimasukkan ke dalam anaerobic jar dan diinkubasi selama 24 jam. Cara mengukur zona hambat dilakukan dengan cara membalik cawan petri lalu kemudian diukur dengan menggunakan jangka sorong. Diameter zona hambat yang terbentuk menunjukkan adanya efek antibakteri dari minyak atsiri sereh dapur.

Analisis data dibuat dengan bantuan komputer melalui program Microsoft Excel dan disajikan dalam bentuk tabel.

\section{HASIL PENELITIAN}

Cawan petri yang sudah diinkubasi di dalam anaerobic jar diambil lalu dilihat Izona hambatnya (Gambar 5). Diameter zona hambat diukur dengan jangka sorong, kemudian luas zona hambat dihitung dengan rumus dan dimasukkan pada tabel pengamatan.

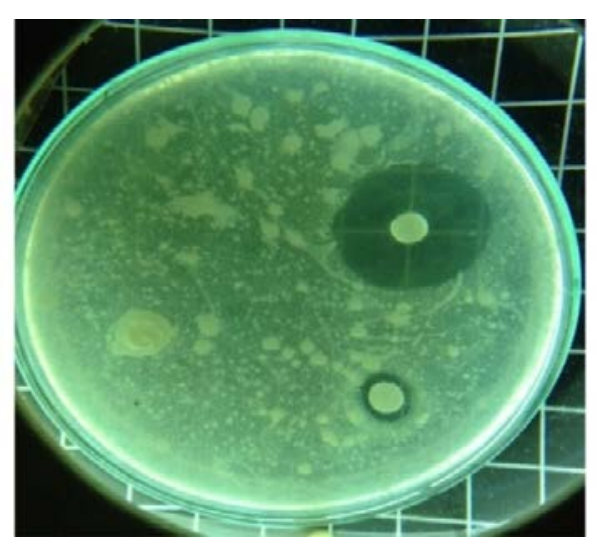

Gambar 1. Zona hambat yang terbentuk pada media MHA. 
Diameter zona hambat yang terbentuk pada media agar MHA kemudian dihitung nilai rata-ratanya. Pada kelompok yang diberikan minyak atsiri sereh dapur dengan konsentrasi $100 \%$ didapatkan nilai rata-rata diameter zona hambat sebesar 5,34 mm, sedangkan pada kelompok kontrol positif klindamisin didapat nilai rata-rata diameter zona hambat sebesar sebesar 23,61 mm dan pada kelompok kontrol negatif didapatkan nilai yang konstan sebesar $0,00 \mathrm{~mm}$. Pada kelompok yang diberi minyak atsiri sereh dapur dengan konsentrasi 75\% didapat nilai rata-rata diameter zona hambat sebesar 4,50 mm, sedangkan pada kelompok kontrol positif klindamisin didapat nilai rata-rata diameter zona hambat sebesar sebesar 24,87 mm dan pada kelompok kontrol negatif didapatkan nilai yang konstan sebesar $0,00 \mathrm{~mm}$ (Tabel 2, Gambar 1).

Tabel 2. Hasil pengukuran diameter zona hambat

\begin{tabular}{|c|c|c|c|c|}
\hline \multirow{3}{*}{ Sampel } & \multicolumn{4}{|c|}{ Konsentrasi } \\
\hline & $25 \%$ & $50 \%$ & $75 \%$ & $100 \%$ \\
\hline & \multicolumn{4}{|c|}{ Diameter Zona Hambat (mm) } \\
\hline $\begin{array}{l}\text { Minyak } \\
\text { Atsiri } \\
\text { Sereh } \\
\text { Dapur }\end{array}$ & 2,60 & 4,73 & 4,50 & 5,34 \\
\hline $\begin{array}{l}\mathrm{K}(+) \\
\text { klindamisin }\end{array}$ & 22,25 & 23,48 & 24,87 & 23,61 \\
\hline $\mathrm{K}(-) \mathrm{CMC}$ & 0.00 & 0.00 & 0.00 & 0.00 \\
\hline
\end{tabular}

Pada kelompok yang diberi minyak atsiri sereh dapur dengan konsentrasi 50\% didapat nilai rata-rata diameter zona hambat sebesar 4,73 mm, sedangkan pada kelompok kontrol positif klindamisin didapat nilai rata-rata diameter zona hambat sebesar sebesar 23,48 $\mathrm{mm}$ dan pada kelompok kontrol negatif didapatkan nilai yang konstan sebesar $0,00 \mathrm{~mm}$. Pada kelompok yang diberi minyak atsiri sereh dapur dengan konsentrasi 25\% didapat nilai rata-rata diameter zona hambat sebesar 2,60 mm, sedangkan pada kelompok kontrol positif klindamisin didapat nilai rata-rata diameter zona hambat sebesar sebesar 22,25 mm dan pada kelompok kontrol negatif didapatkan nilai yang konstan sebesar $0,00 \mathrm{~mm}$ (Tabel 2, Gambar 2).

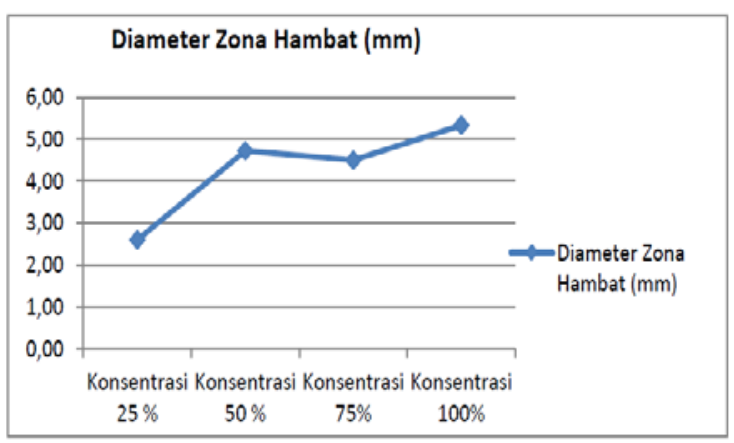

Gambar 1. Diagram diameter zona hambat minyak sereh dapur terhadap Enterococcus faecalis

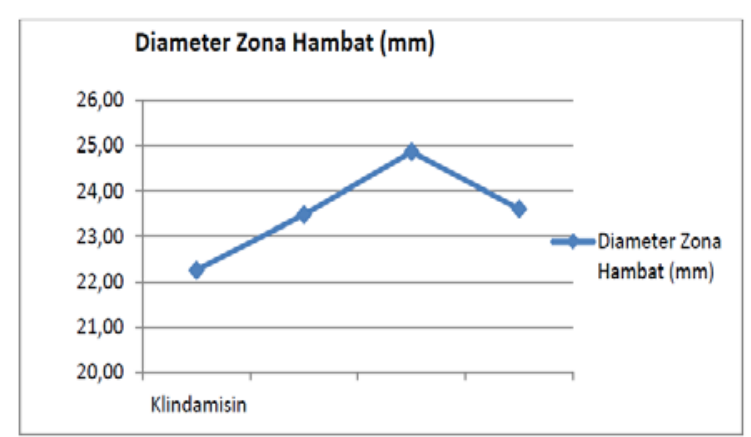

Gambar 2. Diagram diameter zona hambat klindamisin terhadap Enterococcus faecalis

\section{BAHASAN}

Seiring dengan perkembangan zaman, terdapat perkembangan jumlah bakteri yang resisten terhadap antibiotik. Hal ini menjadi masalah dalam dunia kesehatan. Oleh karena itu, telah berkembang berbagai macam obat tradisional sebagai alternatif dalam menghambat perkembangan bakteri. Sereh dapur merupakan salah satu obat tradisional alternatif yang diidentifikasi sebagai senyawa dengan aktifitas antibakteri yang menjanjikan dan dapat digunakan sebagai alternatif obat herbal. Minyak atsiri dari sereh dapur memiliki spektrum antibakteri yang luas. ${ }^{8}$

Penelitian ini merupakan penelitian eksperimental guna mengetahui adanya 
efek antibakteri dari minyak atsiri sereh dapur sebagai bahan medikamen saluran akar terhadap bakteri Enterococcus faecalis. Uji ini dilakukan dengan cara membiakan bakteri Enterococcus faecalis dalam media Mueller Hinton Agar (MHA) dan disertai dengan pelekatan cakram kertas saring yang diberi minyak atsiri sereh dapur dengan konsentrasi 100\%, 75\%, 50\%, 25\%, antibiotik klindamisin sebagai kontrol positif dan digunakan juga kertas saring yang diberi carboxy methyl cellulose (CMC) sabagai kontrol negatif. Kemudian cawan petri diinkubasi ke dalam anerobic jar selama 24 jam. Terlihatnya zona hambat di sekitar cakram kertas saring yang diberi minyak atsiri sereh dapur sehingga menunjukkan bahwa minyak atsiri sereh dapur mampu menghambat pertumbuhan koloni Enterococcus faecalis.

Berdasarkan hasil pengamatan, perbedaan konsentrasi minyak atsiri sereh dapur dapat memengaruhi besarnya daya hambat terhadap bakteri Enterococcus faecalis. Konsentrasi yang memiliki daya hambat terbesar ialah konsentrasi 100\%, jika dibandingkan dengan konsentrasi 25\%, $50 \%$, dan $75 \%$. walaupun relatif lebih kecil dibandingkan dengan antibiotik klindamisin sebagai kontrol.

Hasil penelitian ini didukung dengan penelitian sebelumnya yang dilakukan oleh Hammer. Penelitian ini dilakukan dengan menggunakan metode pengenceran agar dan mengevaluasi efek minyak atsiri sereh dapur pada bakteri Enterococcus faecalis. Hasil penelitian ini menunjukkan aksi antimikroba yang signifikan dari minyak atsiri sereh dapur dengan nilai MIC 12 $\mathrm{pg} / \mathrm{ml}$. Selain itu ada juga penelitian dilakukan Uswantun Nisaa’ Arum Darjono. Penelitian dilakukan dengan analisis minyak atrisi serai sebagai alternatif bahan irigasi saluran akar gigi dalam menghambat pertumbuhan Enteroccocus faecalis. metode penelitian ini dilakukan dengan cara membiakan bakteri Entrococcus faecalis di media MHA. Pada media cawan petri dibuat sumur dengan diameter $6 \mathrm{~mm}$ menggunakan perforator dan dimasukkan minyak atsiri sereh sebanyak 50 $\mu$ l. Hasil penelitian ini menunjukkan konsentrasi minyak atsiri sereh sebesar $20 \%$ memiliki daya hambat terhadap Enterococcus faecalis sebesar 3,278. ${ }^{8,9}$

Klindamisin dijadikan sebagai kontrol positif karena memiliki efek yang sangat baik terhadap mikroba dalam mulut. Klindamisin merupakan antimikroba yang bersifat bakteriostatik maupun bakteriosida. Obat ini umumnya aktif terhadap S. aureus, S. pneumoniae, S. pyogenes, S. Anaerobic, $S$. viridans dan actinomyces isrealli. Klindamisin juga aktif terhadap bacteroides fragilis dan kuman anaerob lainnya. Klindamisin didistribusikan dengan baik ke berbagai cairan tubuh, jaringan dan tulang. Kira-kira 90\% klindamisin dalam serum terikat dengan albumin. Klindamisin berakumulasi dalam leukosit polimorfo-nuklear dan magrofag alveolar tetapi makna klinis dalam fenomena ini belum jelas. ${ }^{10}$

Minyak arsiri sereh dapur memiliki banyak khasiat. Menurut beberapa penelitian minyak atsiri sereh dapur memiliki aktifitas antioksidan, antipiretik, antiinflamasi, penangkal radikal bebas, dan antimikroba. Efektifitas dari minyak atsiri sereh dapur sangat dipengaruhi oleh bahan aktif yang terkandung didalam sereh dapur. ${ }^{7}$ Komposisi dari minyak atsiri sereh dapur sangatlah beragam walaupun memiliki klasifikasi yang sama. Perbedaan komposisi itu sendiri dipengaruhi oleh letak goegrafis, perbedaan genetik, bagian tanaman yang digunakan, metode pengolahan, usia dan musim panen. $^{11}$ Senyawa geranial, neral dan mirsen merupakan komposisi terbesar dalam minyak atsiri sereh dapur. Neral dan geranial termasuk dalam golongan aldehid yang memiliki gugus fungsional karbonil yang terikat pada rantai karbon di satu sisi dan atom hidrogen di sisi yang lain. Citral ialah nama diberikan untuk campuran bahan isomer dari neral dan geranial. Efek antimikroba dari citral cukup baik, tetapi mekanisme hambatan pertumbuhan, cedera sel dan inaktifasi tidak sepenuhnya dipahami. $^{12}$

Keterbatasan dalam penelitian ini yaitu 
peneliti tidak melakukan uji statistik dalam pengolahan data yang mengakibatkan hubungan antar dosis dan efek pada konsentrasi $75 \%$ tidak diketahui apakah turun bermakna atau tidak bermakna.

Penelitian ini menunjukkan bahwa minyak atsiri sereh dapur memiliki memiliki efek antibakteri untuk menghambat pertumbuhan dari bakteri Enterococcus faecalis, namun kemampuan ini masih kurang efektif bila dibandingkan antibiotik klindamisin.

\section{SIMPULAN}

Minyak atsiri sereh dapur memiliki efek antibakteri dalam menghambat bakteri Enterococcus faecalis.

\section{SARAN}

1. Diharapkan dapat menguji efek minyak atsiri sereh dapur terhadap bakteri lain di dalam saluran akar yang menyebabkan kegagalan perawatan saluran akar.

2. Diharapkan pada penelitian selanjutnya agar dapat memilih sereh dengan kualitas terbaik sehingga memiliki kandungan antimikroba yang tinggi.

3. Diharapkan untuk dapat menguji zat aktif dari sereh dapur secara terpisah agar mengetahui cara kerja dari zat aktif minyak atsiri sereh dapur sebagai antimikroba.

\section{DAFTAR PUSTAKA}

1. Mutia R. Efek antibakteri minyak atsiri kayu manis terhadap Enterococcus faecalis sebagai bahan medikamen saluran akar secara in vitro [skripsi]. Medan: Univ. Sumatera utara; 2010.

2. Kalchinov V, Dimitrov SI, Belcheva M. In vitro of bactericidal effect of antimicrobial agents used in modern endodotics, vol. 2. Bulgaria: medical university; 2009: p; 79-83.

3. Fisher K, Phillips C. The ecology, epidemiology and virulence of Enterococcus. Inggris: University of Northampton; 2009; 155: 1749-1757.

4. Rosa OPDS, Torres SA, Ferreira CM, Ferreira FBDA. In vitro effect of intracanal medicaments on strict anaerobes by means of the broth dilution method. Pesqui odontol bras. 2002;16:31-6.

5. Torabinejad W. Prinsip dan praktik ilmu endodonsi, ed. 2. Jakarta: EGC; 1998: p: 307-321.

6. Kusumaningrum W, Rosita II, Awaliyah NM, Kalsum U, Rachmawati A. destilasi uap. Jakarta: Universitas Islam Negari Syahrif Hidayatullah; 2014: p; 1-6.

7. Almeida RBA, Akisue G, Cardoso LML, Junqueira JC, Jorge AOC. Antimicrobial activity of the essential oil cymbopogon citratus (DC) stapf. On staphylococcus spp., streptococcus mutans and candida spp, vol.15. Brazil: Sao Paulo State University; 2013: p. 1-12.

8. Nisa UAD. Analisis minyak atsiri serai (cymbopogon citratus) sebagai alternatif bahan irigasi saluran akar gigi dengan menghambat pertumbuhan Enterococcus faecalis, Majalah Sultan Agung. 2012;49. Semarang: UNISSULA, 2012.

9. Hammer KA, Carson CF, Riley TV. Antimicrobial activity of essential oils and other plant extract. Journal of Applied Microbiology; 2001;86:98590.

10.Gan SG, Setiabudy R, Nafrialdi, Alysabeth. Farmakologi dan terapi. Ed.5. Jakarta: Departemen Farmakologi dan Terapeutik Fakultas Kedokteran, Univ. Indonesia, 2008: p; 727-8.

11.Ranitha M, Abdurahman HN, Ziad AS, Azhari HN, Thana RS. A Comparative Study of Lemongrass (Cymbopogon Citratus) Essential Oil Extracted by Microwave-Assisted Hydrodistillation (MAHD) and Conventional Hydrodistillation (HD) Method. International Journal of Chemical Engineering and Applications. 2014;4:221-6.

12.Luiz BCA, Ulisses PA, Ana MP, Celia MRA, Robson TR, d C Evandro $M$. Evaluation of the Chemical Composition of Brazilian Commercial Cymbopogon citratus (D.C.) Stapf Samples. Molecules. 2008;13:1864-74. 